\title{
The study of 'out-of-school' children and youth situations for developing a lifelong education model for 'out-of-school' children and youth
}

\author{
Pattra Vayachuta $^{1 \mathrm{a}}$, Archanya Ratana-Ubol ${ }^{1}$, and Weerachat Soopanyo ${ }^{1}$ \\ ${ }^{1}$ Department of Lifelong Education, Faculty of Education, Chulalongkorn University, Bangkok \\ 10330, Thailand
}

\begin{abstract}
According to UNESCO, the number of 'out-of-school' children and youth in Thailand is the fifth in Asia and second in ASEAN. Currently, the accumulated number is about 1.7 million people. The purposes of this research are to study 'out-of-school' children and youth situations and method of education provided for them from the related organizations and networks. The results of this study reveal that the problems of the 'out-ofschool' children and youth include low quality of life, lack of life skills and social skills, and behavior problems. The causes are poverty, low achievement in school, and behavior issues which cause dismissal from school. What needs to be provided for them from related organizations are a suitable system of education and vocational skills training. The activities provided by related organizations can be categorized as 1) life skills, social skills and self-esteem enhancement activities 2) funding and resources, which help to open up educational opportunities, and 3) the development of local mechanism to develop them in each area.
\end{abstract}

Keywords: 'out-of-school' children and youth; 'out-of-school' children and youth situations; lifelong education

\section{Introduction}

The term 'out-of-school' children and youth is defined as the population between the ages of 3-25 years who do not attend schools or who have studied in schools but dropped out before completing their compulsory or basic education. This also includes handicapped children or children from families living in poverty who do not have the opportunity to attend schools. Currently, there are over 1.7 million 'out-of-school' children and youth in Thailand [2] the fifth in Asia and the second in ASEAN, after the Philippines, according to UNESCO. Of this, there are more than 580,000 primary-age children who are out-of-school

\footnotetext{
${ }^{a}$ Corresponding author: Pattra.V@Student.chula.ac.th
} 
,[1]. According to a survey conducted by the Office of the Education Council (2014), for the 2012-2013 school year, the retention rate for children who completed their compulsory education (primary - Grade 9) is $81 \%$ while the rate for those who finished their basic education (Grade 12) is $60.7 \%$. This clearly shows that about $40 \%$ of children and youth had dropped out or did not graduate from Grade 12. There are a number of causes for this, including poverty (cannot afford to cover the basic needs, such as food and transportation), and unfavorable living and learning environment which interferes with their studies. All of these problems need to be addressed thoroughly and require a holistic approach to solving them.

\subsection{Background}

The problem of children and youth dropping out from school likely stems from economic and social reasons. According to the study conducted by Quality Learning Foundation in 2012, more than 100,000 girls were pregnant while in school and left to raise their children, more than 60,000 students committed some kind of felonies or crimes and had to enter juvenile observation and protection centers, and more than 600,000 children were under the influence of the drug amphetamine. All of these children and youth were faced with social problems. However, there is another group of children and youth who were faced with financial problems and entered the child labor market to support their families, while others decided to go down the dark paths in order to afford the luxury items that they desire to have. As a result, only about half of the students, about 580,000 children, succeeded in completing their compulsory education, [7]. And the number of those who managed to enter university was 360,000 or $32.4 \%$ only (Child Watch, 2010).

Apart from the issue of students dropping out in the middle of their studies from the above reasons, there is another large group of children and youth, over 5,000,000, who are still in schools, but who are at risk of dropping out anytime due to various factors, as shown in the table below:

Table 1.Number of children who are 'out-of-school' and who are in schools, but are at risk of becoming 'out-of-school' anytime )Quality Learning Foundation ,2012

'Out-of-School' children

Children who are in schools, but are at risk of becoming 'Out-of-School' children
1) Children who dropped out before finishing their basic education $\rightarrow$ about 100,000

2) Teenage mothers $\rightarrow$ about 100,000

3) Drug addicted children / children in juvenile observation and protection centers $\rightarrow$ about 10,000-15,000

4) Homeless children / orphans / child laborers / children living with HIV / child prostitutes $\rightarrow$ about 200,000

5) Children with no nationalities / children of foreign laborers $\rightarrow$ about 500,000

6) Children in southern Thailand broader provinces $\rightarrow$ about 40,000
1) Children from poor families $\rightarrow$ about $3,000,000)$ family income under 20,000 baht/year(

2) $\mathrm{LD} / \mathrm{ADHD} /$ Autistic children $\rightarrow$ about $2,500,000$

3) Children who live in remote areas $\rightarrow$ about 160,000

4) Children in southern Thailand broader provinces $\rightarrow 10,000$ 
A data collected by the Office of the Non-formal and Informal Education in 2009 indicated that there were 141,413 children under the age of 15 who did not complete their compulsory education and dropped out to join the non-formal and informal school system. This shows an increase compared to the previous years. Of this number, 38,936 children dropped out from primary school, 35,364 children left while in the middle of their secondary education (Grades 7-9), and another 67,513 children left school some time during their compulsory and basic education, [3]. Nevertheless, this number is not considered very high if we look at it against the background of the total number of 'out-ofschool' children and youth in Thailand.

The problems that result from this are not only the problems of the dropped out children, but they could lead to other bigger issues, such as crime and labor skills problems as well. An American study has revealed that 'out-of-school' children are 7 times more likely to put themselves at risk than children in school and even live a shorter life span than regular children by 9 years, [5].

Based on the problems mentioned above, this study has been conducted to investigate further on the following issues: current situations of the 'out-of-school' children and youth, relevant statistics, problems and causes of problems which lead to students dropping out from schools, as a way towards developing a lifelong education model for this group of children.

\subsection{Objectives of the Study}

The purpose of this study is to look at the current situations of the 'out-of-school' children and youth as well as to find a way to assist them through the activities provided by related organizations. The insights gained from this study will then help to develop a lifelong education model for the 'out-of-school' children and youth.

\section{Methodology}

In order to assess the current situations of the 'out-of-school' children and youth as well as the problems and causes of the problems, a qualitative research has been conducted, which consists of the following:

1. Literature Review - from existing books, articles, journals, databases, websites, and digital media

2 .In-depth Interview, which is divided into 2 parts, as follows:

2.1 In-depth interview with key informants from related organizations about solutions to problems and ways to assist the 'out-of-school' children and youth.

2.2 In-depth interview with 'out-of-school' children and youth in order to find out about their situations, problems, causes of their problems, and their views on improving their educational opportunities and quality of life.

\section{Results}

From the literature review and in-depth interviews, it has been found that:

1. The 3 main problems of the 'out-of-school' children and youth include:

\section{Low quality of life}

Some of the children who do not go to school or who have dropped out in the middle of their studies have to get low-paying jobs which require no qualifications, while some stay at home with their families. Some of them live in poverty and the children do not get 
the love and attention that they need from their parents. This is then reflected in the way they behave and in their quality of life.

2. Lack of life and social skills

Life and social skills are the skills that children learn while they are in the school system. The government makes sure that these skills are being covered in the basic education syllabus. Therefore, this group of children will be missing these important skills.

3. Likeliness to be engaged in illegal and risky activities

As a result of the above two problems, the 'out-of-school' children and youth are more likely to engage themselves in illegal and risky activities, such as drug and sex-related problems, violence, and gambling.

2. Causes of students leaving the school system come from the following 3 main reasons:

\section{Poverty}

The study results show that many of the problems which the 'out-of-school' children are facing spring from factors related to poverty. Some are children of foreign laborers who have to relocate often and this forces the children to change schools or even drop out in the middle of their studies. Currently, there are more than 3,000,000 children in school, who are from families living in poverty and are, therefore, at risk of dropping out from the compulsory and basic school systems.

\section{Low Achievement in School}

Some of the students are forced to drop out from the school system because of their low performance. Some have study skills problems and cannot follow lessons in class. This lowers their self-esteem and eventually prompts them to drop out of school before completing their compulsory or basic education.

3 Risky behaviors

Some children have to leave school as a result of teen pregnancy, violent behavior, drug problems, crimes, etc.

3. The 'out-of-school' children want to improve 2 things:

1) their educational opportunities, and 2) job skills which are related to their future career.

\section{Assistance given to 'out-of-school' children and youth}

A number of organizations and networks exist in Thailand, which could provide assistance to this group of children. The Office of the Non-formal and Informal Education, for example, is a governmental organization, under the Ministry of Education. They are responsible for educating 'out-of-school' children and youth by developing appropriate educational programs, projects, and activity plans for specific target groups. In 2010, they have developed an educational plan for children who dropped out in the middle of their studies. This plan was in accordance with their principles and based on a flexible action plan, which are suitable for the 'out-of-school' children and youth. Apart from this organization, there is another body under the supervision of the government, called the Quality Learning Foundation. Their aim is to systematically collect information about the 'out-of-school' children and youth as well as the less privileged children in order to provide appropriate assistance on various dimensions, including health care, education, and social and family systems. They are also concerned with building local mechanism and a network of assistance across the country.

\section{Summary}

It is true that the 'out-of-school' children and youth do need to develop many areas in their lives, including their education and life and job skills. However, the traditional school 
system may not be the most suitable place for them because of all the limitations mentioned above. The answer may lie in Lifelong Education, which is based on flexibility and variety, with positive aspects from both the formal, non-formal and informal education , $[4,8$ and 9]. This should open up new possibilities for the 'out-of-school' children and youth and lead them towards a better quality of life.

It is to be noted, however, that this study is part of a needs analysis for the next part of the research. The information and data collected will be carefully analyzed and then used to design a lifelong education model for the 'out-of-school' children and youth. This process will be done in collaboration with the related organizations through a participatory action research.

Remark: This study is a part of "Participatory Action Research for Developing a Lifelong Education Model for Out-of-School Children and Youth by Community Organizations" research.

\section{References}

1. Bangkok Biz., UNESCO concerned the number of primary school age children who were 'out-of-school' children close 600,00. Bangkok Biz News. March 10, 2015, p 15, (2015).

2. Chiangkoon, W. (n.d.). Thai Education State in 2007/2008: Equity and Quality Problems of Education [Online]. Available from: http:// witayakornclub.wordpress. $\mathrm{com} / 2009 / 02 / 23 /$ สภาวะการศึกษาไทย-ปี-5051[March 31, 2012]

3. Child Watch Project, Annual Report: Children and Youth Situations in 2008-2009. Bangkok: Chulalongkorn University Printing House, (2010).

4. Lifelong Education Institute, Educational Principle[Online]. Available from: http://www.lifelonginstitute.com/about-us/[2012, December 21], (2008).

5. Naew Na., 3 million 'Out-of-School' Children! Time to get around "young criminal" problem. Naew $\mathrm{Na}$ News[Online]. Available from: http://www. teenpath.net/ content.asp?ID=12856\#.VYOcCEaMWec[November 15, 2012], (2010).

6. Office of the Education Council., Educational Statistic of Thailand for the 2012-2013 school year. Bangkok: Prikwan Graphic Co.Ltd, p15, (2014).

7. Quality Learning Foundation. Children, Youth and Disadvantage People Situations [Online]. Available from: http://www.qlf.or.th/ Home/ Details?contentId=147[May 13, 2012], (2012).

8. Soonthornpan, N., Lifelong Education Concept. Journal of Human Resource Development, 1(1) [Online]. Available from: http://km.ru.ac. th $/ \mathrm{hrd} /$ Journal/vol_1No_1/nutchanart_1.pdf[August 10, 2012, (2005).

9. Sungsri, S., Lifelong Education for Thai Society in 21 st Century Research Report. Bangkok: The Teachers' Council of Thailand, Lad Prao, (2001). 